\title{
A Linguistic Study of Speech Comprehension and Production in Aphasic Speakers
}

\section{Asst. Lect. Minwas Jamal Rasheed}

Department of English Language and Literature, College of Languages, University of Salahaddin, Erbil, Kurdistan Region of Iraq.

mino ahmed@hotmail.com

\section{Asst. Prof. Dr. Lanja D. Dabbagh}

Department of English Language and Literature, College of Languages, University of Salahaddin, Erbil, Kurdistan Region of Iraq.

lanja.dabbagh@su.edu.krd

\section{ARTICLE INFO}

\section{Article History:}

Received: 27/3/2021

Accepted: 5/5/2019

Published: Autumn 2021

Keywords: Linguistics, Psycholinguistics,

Aphasia, Speech

Comprehension, Speech Production, Syntax, Semantics

Doi:

10.25212/lfu.qzj.6.4.44

\section{ABSTRACT}

Language is a phenomenon that has a central point within the field of linguistics. Among many aspects that are usually tackled within linguistics, the comprehension and the production of language are analyzed as well. Therefore, the two mentioned processes have a specific focus within the domain of linguistics. The ability to produce and comprehend language is usually examined by the speech input and output of speakers with brain damage. The current research tries to highlight a linguistic investigation by focusing on the speech comprehension and production of individuals with aphasia. That is why the aim of this research is to analyze the linguistic matters of spoken language input and output that are usually weakened as an outcome of brain damage such as stroke. In addition, the present work tries to reveal possible characteristics of aphasic speakers that show clear difficulties during speech input and output due to brain injury. The method of the study consists of semi-structured interviews with aphasic speakers that are collected by visiting a number of different public and private hospitals and physiotherapy centers in Erbil. The tests are done by using picture presentation techniques and a questionnaire related to background information of the participants. Aphasic individuals are shown a number of different types of pictures 
and are asked to answer specific questions related to the events within the pictures. Their linguistic state is then examined by analyzing their answer syntactically and semantically.

\section{Introduction}

The human brain consists of specific areas that are responsible for processing all the abilities of the use of language such as reading, writing, listening and speaking. The ability to organize language may sometimes be disturbed by a certain brain damage that usually leads to a malfunction in processing language through the brain. The outcome of language impairments due to brain injury is commonly known as aphasia. Aphasia is an acquired language disorder due to focal brain damage that must have occurred after the period of language development. The presence of aphasia is the result of several causes of brain damage whereas a cerebrovascular accident (CVA), also known as stroke, is the most common one. By focusing on the location that is responsible of language use, and by depending on the size of the brain lesion, aphasia usually creates speech comprehension and production disorder (Reinvang, 1985).

Traxler (2012) argues that aphasia may be unfamiliar to many people but it is not a rare phenomenon in the field of linguistics, and, certainly not in the field of psycholinguistics. From a linguistic point of view, many tests could be used to study the linguistic knowledge of aphasics. The most frequently used way to test the state of their language comprehension and production is syntactical.

\section{Language}

Apart from the main branches of language such as; phonetics and phonology, morphology, syntax, semantics, and pragmatics, linguistics also includes a phenomenon called language and the brain. In other words, linguistics does not only examine human sounds, the internal structure of words, the creation of sentences, the study of meaning or the use of language in specific situations. Linguistics is also concerned with how language is managed by and within the brain. For this purpose, many linguists have shared their knowledge concerning language and mind. 


\section{QALAAI ZANISTSCIENTIFIC JOURNAL \\ A Scientific Quarterly Refereed Journal Issued by Lebanese French University - Erbil, Kurdistan, Iraq \\ Vol. (6), No (4), Autumn 2021 \\ ISSN 2518-6566 (Online) - ISSN 2518-6558 (Print)}

The scholar Bloomfield explains that language is basically a process of expressive movements. That is why, Bloomfield defines language as: "language is the form of expressive movement adequate to the mentality of man" (1983, p. 16). Bally and Sechehaye argue that according to Ferdinand de Saussure, language is a complex system of rules and relations. This complex system is made up of signs (words) and these signs consist of two parts, namely, one part is the sound and form while the other part is its meaning. On the other hand, de Saussure claims that words are stored in the mind of the speakers (1966). According to Sapir and Whorf, language and thought influence each other (Traxler, 2012). Whorf and Sapir claim that the system of language along with its rules of vocabulary is essential for thought. The linguistic system (grammar) of each language invents ideas, programs, and guides each individual's mental activity (Steinberg and Sciarini, 2006). On the other hand, Chomsky argues that language is basically an inborn or innate matter. Chomsky believes that language knowledge is a part of the speaker's mind. That is why knowledge of language is already present in the mind of the speaker. Important knowledge of language such as grammar is not acquired from experience because it is already there in the mind of the speaker (Cook and Newson, 1996).

Based on the mentioned beliefs from influential linguists it can be pointed out that the use of language is related to the human mind. That is to say, any linguistic input must be psychologically processed by the human mind. However, in order to understand how linguistic input is normally processed by the human mind, one has to understand how language is actually being processed by the human brain.

\section{Language and the Brain}

The use of language such as comprehending and producing speech, including reading and writing, is processed by the most complex organ which is the human brain. The human brain consists of particular regions that are involved in the comprehension and production of spoken language.

The human brain is structured in areas that are responsible for specific tasks. According to the structure of the human brain, Steinberg and Sciarini (2006) describe in their book, An Introduction to Psycholinguistics, the human brain is divided into two 


\section{QALAAI ZANISTSCIENTIFIC JOURNAL}

A Scientific Quarterly Refereed Journal Issued by Lebanese French University - Erbil, Kurdistan, Iraq

Vol. (6), No (4), Autumn 2021

ISSN 2518-6566 (Online) - ISSN 2518-6558 (Print)

halves. The left half is called the left hemisphere while the right one is remarked as the right hemisphere. Both hemispheres are involved in higher brain functions such as memory, attention, perception, cognition, awareness, consciousness, thought, and not to forget language. The picture below shows a clear overview of the human brain structures and their functions.

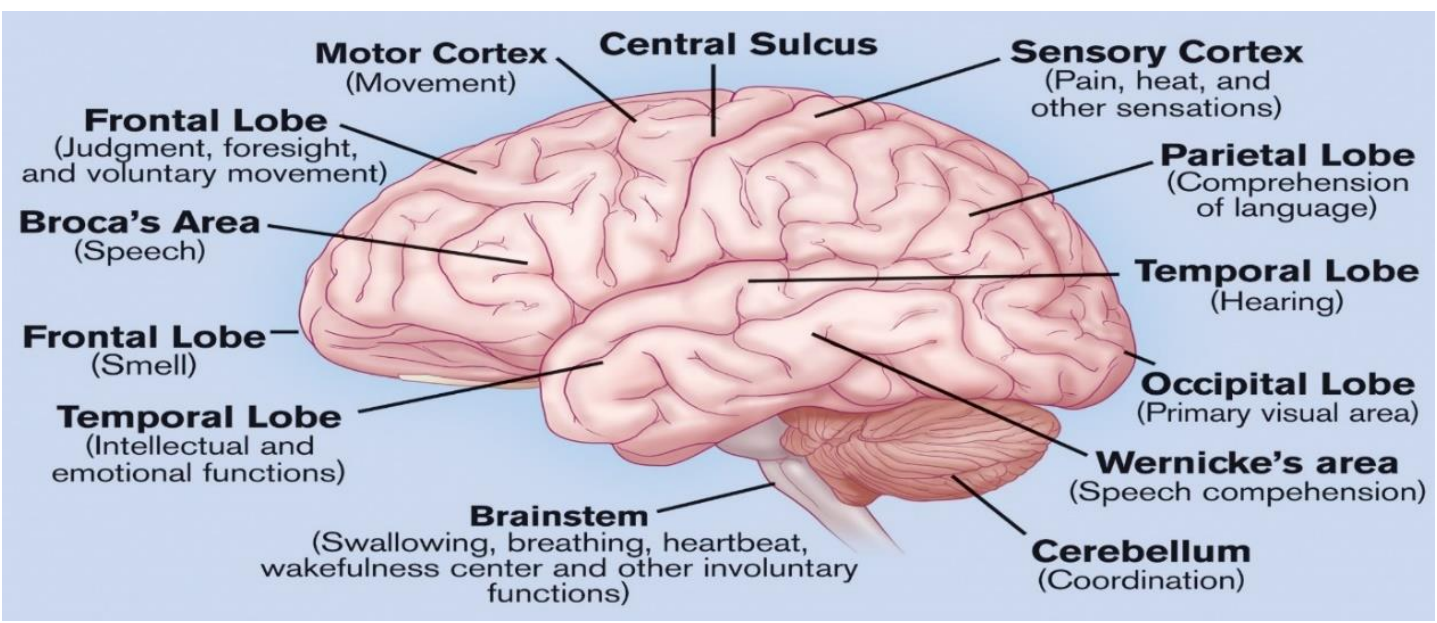

Figure 1: [Brain Structures and their Functions] n. d. [image online] Available at: <http://www.ganino.com/brain_structures_and_their_functions> [Accessed 7 November 2018].

Figure 1 emphasizes the regions and their functions of the left hemisphere. Helmut Schnelle (2010) describes the areas that are important for the organization of language such as comprehending and producing speech are called Broca's area and Wernicke's area.

Regarding understanding and the creation of spoken language, Broca's area is a specific area that is situated in the left hemisphere and is crucially responsible for the production of speech. On the other side, Wernicke's area is a particular area that is also situated in the left hemisphere, but, this area is crucially involved in the understanding of speech. It is worth to mention that the mentioned areas together are certainly not enough to use language. Therefore, there are two other areas that are also involved during language use. These two areas are called the motor cortex 


\section{QALAAI ZANISTSCIENTIFIC JOURNAL \\ A Scientific Quarterly Refereed Journal Issued by Lebanese French University - Erbil, Kurdistan, Iraq \\ Vol. (6), No (4), Autumn 2021 \\ ISSN 2518-6566 (Online) - ISSN 2518-6558 (Print)}

and the arcuate fasciculus. The motor cortex is responsible for the movements of the muscles that are necessary for the articulation of speech. The arcuate fasciculus is crucial for the connection between understanding speech and producing speech (Yule, 2010). Figure 2 shows a clear overview of the areas that organize speech input and output.

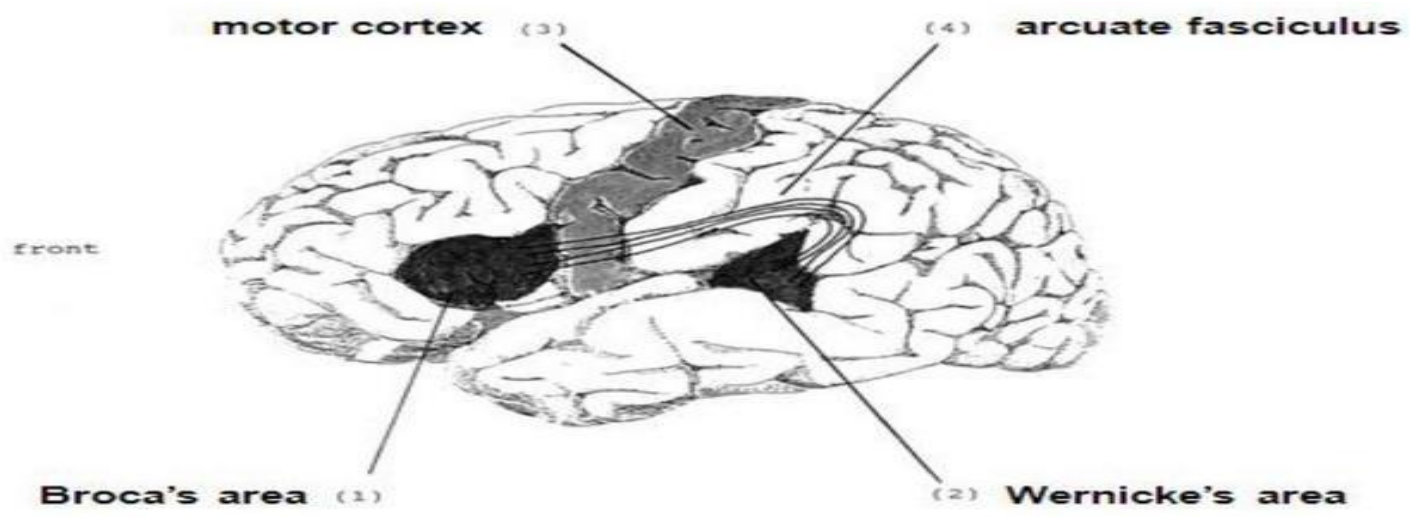

Figure 2 [Broca's area, Wernicke's area, the motor cortex, and the arcuate fasciculus] 2014 [image online] Available at <https://twitter.com/island123_y/status/489071183451521024> [Accessed 7 November 2018].

\section{Language Comprehension}

Lieberman (2000) explains that Wernicke's area is responsible for the comprehension of language. This region in the brain processes incoming speech signals such as words or sentences. Traxler (2012) concludes that according to Carl Wernicke, who was the first person that found disorders in speech comprehension, language comprehension is usually accomplished because of two types of remembered images in the brain. One group of images contains phonological (sound) information in connection with words. The other set consists of conceptual/semantic (meaning) information.

Carl Wernicke and Ludwig Lichtheim created a model called the Wernicke-LichtheimGeschwind (WLG) model of language organization in the brain. This model explains 


\section{QALAAI ZANISTSCIENTIFIC JOURNAL \\ A Scientific Quarterly Refereed Journal Issued by Lebanese French University - Erbil, Kurdistan, Iraq \\ Vol. (6), No (4), Autumn 2021 \\ ISSN 2518-6566 (Online) - ISSN 2518-6558 (Print)}

the process of speaking, reading but most importantly perceiving language. The WLG model is elaborated in the next figure as follows.

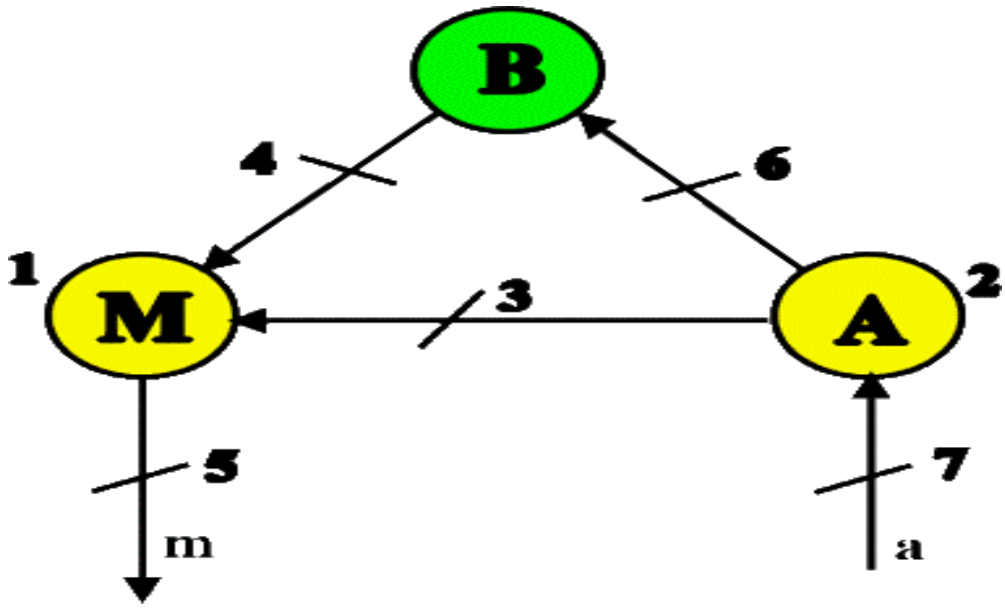

Figure 3: The Wernicke-Lichtheim-Geschwind "house" model of the neural architecture of language, 2015, p. 74

A clarification of the above model is as follows, the symbol ' $M$ ' stands for the center of speech planning and production which is Broca's area. The sign ' $A$ ' represents the center that is responsible for storing information about word sounds which is the Wernicke's area. While ' $\mathrm{B}$ ' is the place that contains the meanings of words. The letter ' $a$ ' which is situated bottom right represents auditory input and the letter ' $m$ ', bottom left, represents the motor articulatory center for speech production. The arrows show the direction of information flow. The numbered slanted lines represent lesion sites that usually cut connections between the centers (Kemmerer, 2015).

\section{Language Production}

According to Jean Aitchison explains "there has been less research on language production than on language comprehension" (2008, p. 234). That is why the analyses of the production of speech are usually more complex if compared with the comprehension of speech. However, among all sources related to speech production, Levelt's theory of the mental process during speech output which is also called the 


\section{QALAAI ZANISTSCIENTIFIC JOURNAL \\ A Scientific Quarterly Refereed Journal Issued by Lebanese French University - Erbil, Kurdistan, Iraq \\ Vol. (6), No (4), Autumn 2021 \\ ISSN 2518-6566 (Online) - ISSN 2518-6558 (Print)}

WEAVER++ model is the most trusted theory regarding spoken language output. The model is shown in the next figure along with a further explanation of its content.
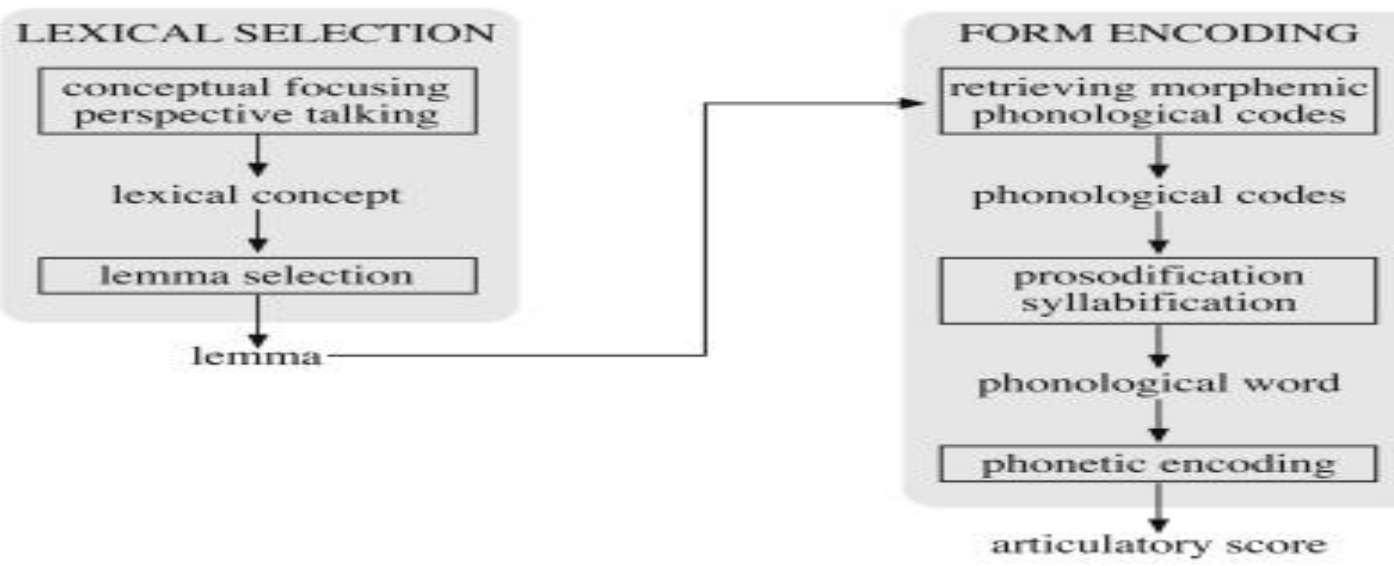

Figure 4: Serial two-system architecture of the theory: two stages of lexical selection followed by three stages of form encoding, 2001.

The explanation of figure 4 is as follows, in order to articulate a word, one has first to choose an appropriate item from the mental lexicon. This stage is called lexical selection. Then, the articulatory shape of the selected item will be prepared which is called form encoding. According to lexical selection, imagine someone is shown a picture of a horse and is asked about what the picture contains. The subject may have various interpretations of the content of the picture, so, instead of saying horse the subject may say stallion or animal (Levelt, 2001). Therefore, the first step in preparing a content word is to concentrate on a concept whose expression serves a particular communicative goal which is called perspective talking. In order to choose a lexical item, perspective talking forces the speaker towards the level of lexical concept. To start the lexical selection the speaker must focus on the lexical concept which may be a horse, stallion and an animal. The theory assumes that during perspective talking there is co-activation of related concepts. Each corresponding lexical items in the speaker's mental lexicon is termed as a lemma. A lemma is a lexical item's syntactic description, for example, the lemma for horse supports that horse is a count noun that may have a singular or a plural form. When the speaker has reached the lemma 


\section{QALAAI ZANISTSCIENTIFIC JOURNAL \\ A Scientific Quarterly Refereed Journal Issued by Lebanese French University - Erbil, Kurdistan, Iraq \\ Vol. (6), No (4), Autumn 2021 \\ ISSN 2518-6566 (Online) - ISSN 2518-6558 (Print)}

the lexical selection is finalized. Due to the selected lemma, the stage of phonological codes will be activated. However, no other codes will be activated as well, in other words, if the selected concept is 'horse' the co-activated lemmas stallion and animal will remain silent. Next, phonological codes are spelled out as ordered sets of phonological segments (units of sounds). This is called prosodification which mainly consists of syllabification. The phonological segment completes the process of syllabification by forming a phonological word. Then, the syllable or syllables are put in the final encoding step which is phonetic encoding. When this is done, the final output is the articulatory score which consists of the execution of the successive use of the organs of speech in order to produce overt speech (Levelt, 2001).

\section{Language Comprehension and Production Disorder}

Brain damage most frequently causes language disorder. Among the four possible ways that usually result in focal brain damage, each way may end up in language disorder. The most frequent cause of language disorder is called cerebrovascular accident (CVA), also known as stroke. The other causes might be traumatic brain injury which is also known as TBI, brain tumor or brain infection (Groenewold, 2015).

\section{Aphasia}

In the field of linguistics and neurology, the type of language disorder that results from the mentioned causes of brain damage are often labelled as aphasia. This language impairment is usually grouped into two classes, namely, non-fluent and fluent aphasia. Non-fluent aphasia refers to relatively preserved verbal comprehension, but serious articulation and spoken production problems. While fluent aphasia is characterized by fluent speech and normal articulation but difficulties in auditory comprehension (Stemmer and Whitaker, 2008).

Aphasia consists of the following types; Broca's Aphasia, Wernicke's Aphasia, Conduction Aphasia, Global Aphasia, Anomic Aphasia, Transcortical Motor Aphasia, Transcortical Sensory Aphasia and lastly Mixed Transcortical Aphasia. Among the mentioned types of aphasia, Broca's aphasia and Wernicke's aphasia are the most common ones. 


\section{QALAAI ZANISTSCIENTIFIC JOURNAL \\ A Scientific Quarterly Refereed Journal Issued by Lebanese French University - Erbil, Kurdistan, Iraq \\ Vol. (6), No (4), Autumn 2021 \\ ISSN 2518-6566 (Online) - ISSN 2518-6558 (Print)}

The most important characteristics of Broca's and Wernicke's aphasia are shown in the table below.

Table 1 Complementary symptoms of Broca's and Wernicke's aphasia cited in Ingram, 2007, p. 51

\begin{tabular}{|c|c|}
\hline Broca type & Wernicke type \\
\hline - dysfluent effortful speech & - fluent but empty speech, normal \\
- $\quad$ the absence of function words and & prosody \\
$\quad$ inflectional morphology & function words and grammatical \\
- $\quad$ short utterances & inflections present \\
$-\quad$ relatively intact comprehension & - utterances of normal length \\
$-\quad$ awareness of deficit & - poor comprehension \\
& - unaware of deficit \\
\hline
\end{tabular}

During the majority of tests that have been done during previous studies in aphasic speakers, the linguistic field of syntax has been the most frequently used manner for measuring aphasic speakers' language ability. Within the level of syntax, prepositions are usually used to check one's capability of speech input and output. Steinberg and Sciarini (2006) argue that Broca's aphasia is characterized by often lacking prepositions. Code (1996) points out that in a clinical task on the use of prepositional phrases during speech output, even Wernicke's aphasics have been shown to use fewer prepositional phrases during the test. The researchers Tranel and Kemmerer examined a number of aphasic individuals concerning their knowledge of the meaning of locative prepositions. Words like in, on, around, though, above and below are locative prepositions that are used to identify locations. During the test, some failed none of them, others failed just one, others two, others three and others all four. This shows that aphasic individuals do have problems with the comprehension and production of prepositions (Kemmerer, 2015).

It would be worth to take a look at the functions and role of prepositions in the English language and as well as in the Kurdish language since the participants of this research use the Kurdish language as their mother-tongue.

In English, prepositions are used to provide information about location time and manner. Words like, 'under', 'over', 'into' and 'towards' are locative prepositions because they mark locations. Words such as, 'before', 'during', 'after', 'until' and 


\section{QALAAI ZANISTSCIENTIFIC JOURNAL \\ A Scientific Quarterly Refereed Journal Issued by Lebanese French University - Erbil, Kurdistan, Iraq \\ Vol. (6), No (4), Autumn 2021 \\ ISSN 2518-6566 (Online) - ISSN 2518-6558 (Print)}

'since' are temporal prepositions because they identify time. Words like, 'with' or 'in' as in the utterances; 'with the knife' or 'in a loud voice' are prepositions of manner because they describe an event (Tallerman, 2015). Nordquist (2018) highlights that besides conveying information about location, time and manner, prepositions have also the property to express other kinds of information. There are prepositions that refer to directions as the preposition 'to' as in: 'to the south'. Also, some prepositions function merely for building relationships such as the prepositions, 'with', 'without' or 'within'. Also, Nordquist (2018) highlights that prepositions are of two groups; simple prepositions and complex prepositions. Simple prepositions consist of short words such as, 'at', 'by', 'for' and 'of'. Complex prepositions include the combination of two or three-word units with one or two simple prepositions such as, 'in addition to', 'such as, 'thanks to' or 'in between'.

Thus, generally speaking, in English, the task of prepositions is to clarify the location, time or manner of a certain event. Interestingly, the same function counts for prepositions in the Kurdish language. That is why it would be worth to get more knowledge about this phenomenon in Kurdish.

The dialect that is spoken by the participants of this study is called the Central Kurdish dialect which is also known as Sorani. That is why it would be more reasonable to take a closer look at prepositions within this Kurdish dialect.

Kurdish includes simple prepositions and compound prepositions. Simple prepositions consist of the following ones: 'le', 'be', 'bo', 'bê' and '(he)ta'. The preposition 'le' comes either alone or with the suffixes - da or -we. 'le' usually gives information about location, time or manner.

(1) According to location: 'le' identifies the location of an event, as in, 'malli dara le teništ supermarkitekeye' (Dara's house is next to the supermarket)

(2) Regarding time: 'le' identifies the time of an event, as in, 'dara le seat dŭda royšit (Dara left at two o'clock)

(3) Concerning manner: 'le' identifies the cause of an event, as in, 'em nexošiye le xuwardinewey awı̆ pise' (this illness comes from drinking unclean water). 


\section{QALAAI ZANISTSCIENTIFIC JOURNAL \\ A Scientific Quarterly Refereed Journal Issued by Lebanese French University - Erbil, Kurdistan, Iraq \\ Vol. (6), No (4), Autumn 2021 \\ ISSN 2518-6566 (Online) - ISSN 2518-6558 (Print)}

Similar to the previous simple preposition 'le', the simple preposition 'be' modifies location, time and manner as well.

(1) Location: 'dara be jurekeda têperi’' (Dara walked along the door)

(2) Time: 'dara be sê roj geyšte hewler' (Dara arrived within three days in Hawler)

(3) Manner: 'dara be bašı babetekey rŭnkirdewe' (Dara clearly explained the subject)

Concerning 'bo', the preposition 'bo' also indicates location, time and manner.

(1) Location: 'dara gerayewe bo malli xoy' (Dara returned to his home)

(2) Time: 'dara bo beyani namekey birdewe bo birakey' (Dara returns the letter to his brother by tomorrow)

(3) Manner: ' $\mathrm{min}$ bo to dejim' (I live for you)

Regarding 'bê', it usually indicates persons or objects.

(1) Indicating a person: 'min bê to najĭm' (I cannot live without you)

According to (he)ta, this preposition refers to time and length.

(1) Indicating length: 'min heta kerkuk deçim' (I go till Kirkuk)

(2) Indicating time and length: 'min ta hefteyek lêre demênmewe' (I'll stay here for one week)

Switching to compound prepositions, compound prepositions in Central Kurdish dialect includes either a combination of two simple prepositions or a combination of a simple preposition and a noun. The sequence simple preposition plus simple preposition is as the following example; 'be + bê' = bebê (without). According to the pattern simple preposition plus a noun, this is illustrates as follows; 'le' + 'ber' = 'leber' (because), 'le' + 'jêr' = 'lejêr' (under), 'le' + 'naw'/'new' = 'lenaw'/'lenêw' (inside), 'le' + 'ser' = 'leser' (above), 'le' + 'pêš' = 'lepêš' (in front), 'le' + 'paš' = 'lepaš' (behind), 'le' + 'diwa' = 'lediwa' (after) and 'le' + 'bin' = 'lebin' (under). Regarding the simple preposition 'be' plus a noun; 'be + paš' = 'bepaš (after), 'be' + 'pêš' = 'bepêš' (before),

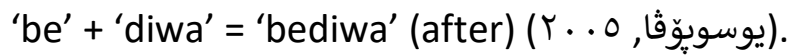




\section{QALAAI ZANISTSCIENTIFIC JOURNAL \\ A Scientific Quarterly Refereed Journal Issued by Lebanese French University - Erbil, Kurdistan, Iraq \\ Vol. (6), No (4), Autumn 2021 \\ ISSN 2518-6566 (Online) - ISSN 2518-6558 (Print)}

\section{Treatments for the Recovery of Aphasia}

In his book, Introduction to Psycholinguistics, Traxler (2012) argues that individuals with aphasia do not always permanently suffer from this type of language disorder. Sometimes, speakers with aphasia recover considerably from their language impairments. The signs of recovery may already start as soon as a few days after the injury. However, the process of recovery can possibly stretch over several months to several years. The reason for this type of recovery is the fact that the non-damaged right-hemisphere has the ability to take over some of the language functions that were previously processed by the damaged left-hemisphere. Another option for the recovery of aphasia could be pharmacological therapy (drugs). The best time to apply pharmacological treatments for improving linguistic impairments is immediately after the stroke occurs. Furthermore, the combination of speech therapy and pharmacological therapy at the same time is considered as the best option to get a positive result in the recovery of aphasia (Traxler, 2012).

\section{Conclusion}

In summary, this paper has tried to explain, from a linguistic point of view, how aphasia affects the comprehension and production ability of speakers with this type of speech disorder. The affections of aphasia regarding speech comprehension and production consist of either having problems in the articulation of speech output or difficulties in the comprehension of speech input. The work started to expose different viewpoints from influential scholars concerning language and mind. From Chomsky's perspective regarding language and mind, he argues that language is an innate or inborn process. In other words, language is already there in the mind of the speaker. Similarly to Chomsky's viewpoint, the scholar de Saussure concludes that language is a complex system of rules and relations that consists of words which are stored in the mind of the speakers.

Also, the process of speech comprehension and production was highlighted by sharing two useful models concerning speech input and output. The first model that is used for the organization of language in the brain is labelled as the WLG (WernickeLichtheim-Geschwind) model which gives an interesting overview concerning the 


\section{QALAAI ZANISTSCIENTIFIC JOURNAL \\ A Scientific Quarterly Refereed Journal Issued by Lebanese French University - Erbil, Kurdistan, Iraq \\ Vol. (6), No (4), Autumn 2021 \\ ISSN 2518-6566 (Online) - ISSN 2518-6558 (Print)}

perception of language. The second model, WEAVER++ which is created by the famous Dutch psycholinguist Willem Levelt elaborates the complete mental process of speech output.

The reason and outcome of speech errors were then discussed by explaining the aspects of a commonly known language disorder named aphasia. Aphasia is an acquired language disorder due to focal brain damage such as a cerebrovascular accident (CVA) that must have been occurred after the period of language development.

Also, the linguistic field of syntax has been taken into consideration by focussing on prepositions in English and specifically in the Kurdish language. It can be concluded that the role and the function of English prepositions are similar to Kurdish ones.

Lastly, aphasia has possible ways to be recovered. Among them is the combination of pharmacological and speech therapy the ideal treatment.

\section{References}

Aitchison, J. (2008) The articulate mammal. London: Routledge.

Bally, C. and Sechehaye, A. (eds.) (1966) Course of General Linguistics: Ferdinand de Saussure. New York: McGraw-Hill Book Co.

Bloomfield, L. and Kess, J. (1983) Introduction to the Study of Language. Amsterdam: John Benjamins Publishing Company.

Code, C. (ed.) (1996) Forums in Clinical Aphasiology. Compton Terrace: Whurr Publishers Ltd. Cook, V. J. and Newson, M. (eds.) (1996) Chomsky's Universal Grammar: An Introduction. Oxford: Blackwell Publishers Ltd.

Groenewold, R. (2015) Direct and indirect speech in aphasia. Ph.D. thesis, University of Groningen, Zutphen.

Kemmerer, D. (2015) Cognitive Neuroscience of Language. New York: Psychology Press.

Levelt, W. J. M. (2001) 'Spoken word production: A theory of lexical access', National Academy of Sciences, pp. 8.

Lieberman, P. (ed.) (2000) Human Language and Our Reptilian Brain: the subcortical bases of speech, syntax, and thought. Cambridge: Harvard University Press.

Nordquist, R. (2018) Prepositions in English Grammar. Available at: https://www.thoughtco.com/preposition-english-grammar-1691665 (Accessed: 19 November 2018.

Reinvang, I. (1985) Aphasia and Brain Organization. Applied Psycholinguistics and Communication Disorders New York: Plenum Press, p. 27. 


\section{QALAAI ZANISTSCIENTIFIC JOURNAL}

A Scientific Quarterly Refereed Journal Issued by Lebanese French University - Erbil, Kurdistan, Iraq

Vol. (6), No (4), Autumn 2021

ISSN 2518-6566 (Online) - ISSN 2518-6558 (Print)

Schnelle, H. (2010) Language in the Brain. Cambridge: Cambridge University Press.

Steinberg, D. D. and Sciarini, V. N. (eds.) (2006) An Introduction to Psycholinguistics: Danny D. Steinberg \& Natalia V. Sciarini. second edn. London: Routledge.

Stemmer, B. and Whitaker, H. A. (eds.) (2008) Handbook of the Neuroscience of Language. first edn. San Diego: Elsevier.

Traxler, M. J. (2012) Introduction to Psycholinguistics: understanding language and science. Chichester: Wiley-Blackwell.

Yule, G. (ed.) (2010) The Study of Language. fourth edn. Cambridge: Cambridge University Press.

يوسويوّثا، ز.، ه.r. شيّوهى سليّمانى زمانى كوردى، وهرگيّيردراوه له زمانى رووسيهوه بوّ سهر زمانى كوردى له لايهن موكريانى، ك.، ههولِيّر: كوّرى زانيارى كوردستان.

\section{لِيكوَّلِينهوهيه كى زمانهوانى لهسهر بهرهه مهيّنان و تيّكَهيشتنى ئاخاوتن له نيّو قسه كهرانى ئافازى}

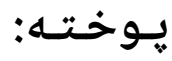

زمـان ديـاردهيهكه، شــويْنيّكى ديـاريكراوى لهنيّو بوارى زمـانهوانيــا ههيه. لهنيّوان ئهو لايهنه زمانهوانيانهى، كه له زماندا هه بوونيان ههيه، تيكگيشـتن و بهرههمهيّنانى قســه رهجاودهخيريّن و ليّييان دهكوّليّدريتهوه، بوّيه ههردوو يروّسهى تيّكه يشتن و بهرههمهيّنانى قسه شويّنى تايبهتى خوّيان

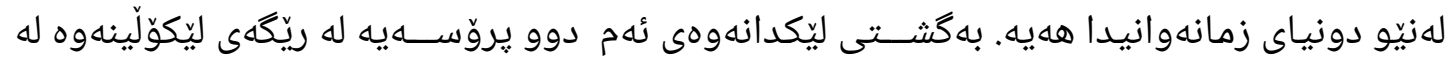
رادهى تيّكهيشتن و بهرهه مهينانى ئاخاوتن لهلايهن ئهو كهانهى، كه ميّشكيان تيّكجووه، يان ئهوانهى هيجه كيّشـيان له ميّشكدا نييه. لهم ليّكوّلِينهوهيهدا ههولدراوه تيشك بخريّته سهر ئهو كهسانهى، كه

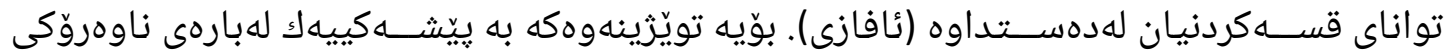
ليّكوَلِينهوهكه دهستيِيِيدهكات، بهشى دووهمى بهكورتى يهيوهندى زمان به ميّشـى مروّقهوه لهنيّو بهرههمى زمانهوانانى يسـيوّرانى ئهم بواره دهخاتهروو. بهشى سـيّيهم يِيّكهاتهى مييّيشـى مروّق و و

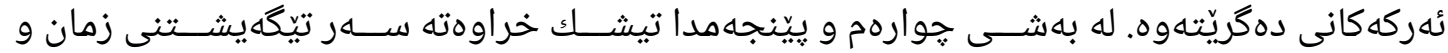

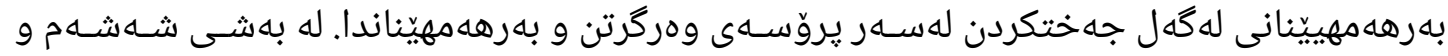
ههوتهمدا تايبهتمهندى تيّكُوون و شلّهزان له تيّكهيشتندا روونكراوهتهوه، لهريّكَى دياردهيهكى زوّر ناسـراو، كه ييّوهندى به زمانهوه ههيه، ئهويش لهدهسـتدانى تواناى قســـكردنه (ئافازى). له بهشـى 


\section{QALAAI ZANISTSCIENTIFIC JOURNAL}

A Scientific Quarterly Refereed Journal Issued by Lebanese French University - Erbil, Kurdistan, Iraq

Vol. (6), No (4), Autumn 2021

ISSN 2518-6566 (Online) - ISSN 2518-6558 (Print)

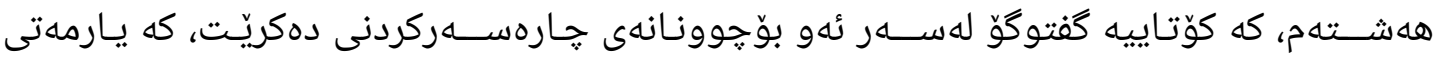

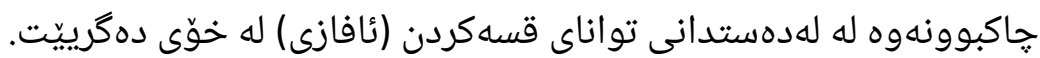

الملخص:

اللغه هى فاهره تحتل موقع مركزى فى مجال اللغويات. ومن بين العديد من الجو انب التى تعالج عاده فى مجال

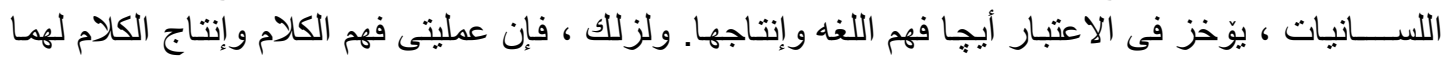

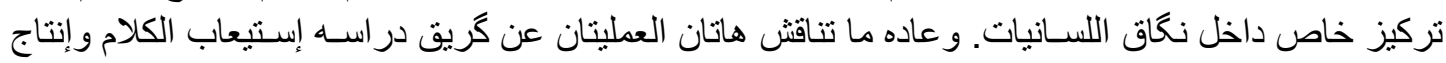

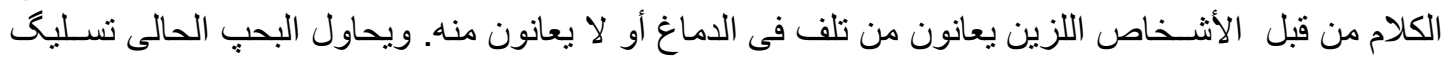

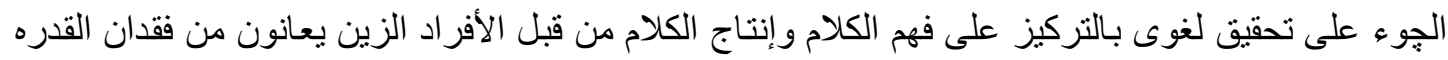

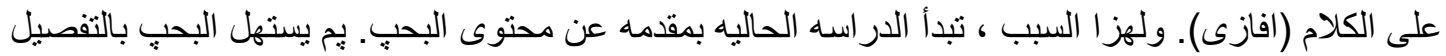

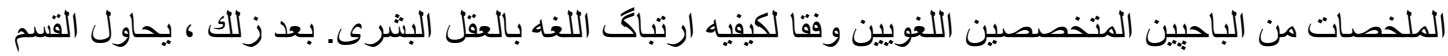

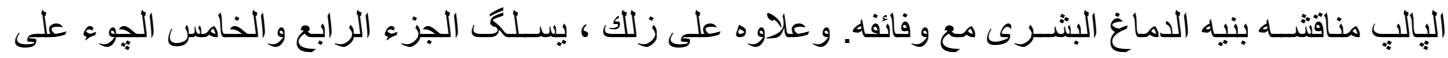

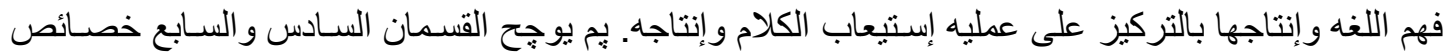

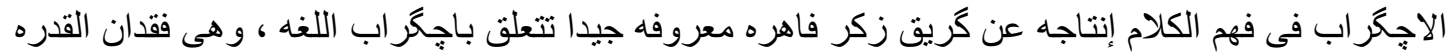

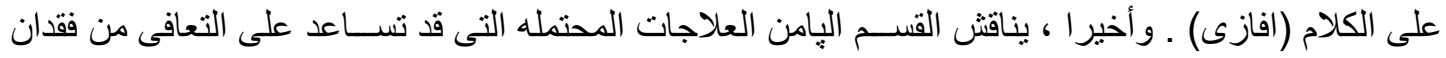
القدره على الكلام (افازى). 